\title{
KONTRADISKURSUS MAKNA JIHAD SEBAGAI TEROR DI MEDIA ONLINE SUARAMUHAMMADIYAH.ID DAN NU ONLINE
}

\section{COUNTER-DISCOURSE THE MEANING OF JIHAD AS TERROR IN ONLINE MEDIA SUARAMUHAMMADIYAH.ID DAN NU ONLINE}

\author{
Said Romadlan $^{\left.1^{*}\right)}$, Dimas Prasetyo Wibisono ${ }^{2}$, Zulfa Triwahyuningsih $^{3}$ \\ 1,2,3 Program Studi Ilmu Komunikasi Universitas Muhammadiyah Prof. Dr. HAMKA. \\ Jl. Limau II, Kebayoran Baru, Jakarta, Indonesia \\ ${ }^{1}$ saidromadlan@uhamka.ac.id; ${ }^{2}$ dimasprasetyowibisono27@gmail.com; ${ }^{3}$ zulfatrw@gmail.com
}

Diterima tgl. 22/09/2021; Direvisi tgl. 17/11/2021; Disetujui tgl. 18/11/2021

\begin{abstract}
After the reform in 1998, the discourse of radical Muslim groups strengthened in proclaiming their views through online media owned. They proclaimed a Khilafah to replace Pancasila, jihad as war, and intolerance towards non-Muslims. Discourse on radicalism regarding jihad in online media must be countered with counter-discourse on the other meaning of jihad through online media suaramuhammadiyah.id and NU Online, both are Muhammadiyah and Nahdlatul Ulama (NU) official media. The research problem is how do forms of counter-discourse of meaning of jihad through suaramuhammadiyah.id and NU Online? The aim is to demonstrate the forms of counter-discourse meaning of jihad through suaramuhammadiyah.id and NU Online. The study used Norman Fairclough's method of critical discourse analysis, which focused his analysis on three levels: (1) text analysis, (2) analysis of discourse practice, and (3) socio-cultural analysis (context). The results showed that the counter-discourse forms of radicalism by suaramuhammadiyah.id is to represent it as jihad lil-muwajahah (earnestly creating something superior). While NU Online represent the meaning of contextual jihad such as jihad against corruption, against drugs, against hoaxes, and so on. The implications of this study confirm that the discourse represented by suaramuhammadiyah.id and NU Online is a counter-discourse on jihad as war or violence planned by radical Muslim groups. In conclusion, online media suaramuhammadiyah.id and NU Online have a strategic role in countering and countering radicalism discourse, especially regarding jihad as war from radical Muslim groups in Indonesia.
\end{abstract}

Keywords: Counter-radicalism, jihad, online media, suaramuhammadiyah.id, NU Online

\begin{abstract}
ABSTRAK
Pascareformasi tahun 1998, diskursus kelompok-kelompok muslim radikal menguat dalam mewacanakan pandangan-pandangannya melalui media-media online yang dimiliki. Mereka mewacanakan sistem pemerintahan khilafah pengganti Pancasila, jihad sebagai perang, dan intoleransi terhadap nonmuslim. Diskursus radikalisme mengenai jihad di media online harus dilawan dengan kontradiskursus makna jihad yang lain, salah satunya melalui media online suaramuhammadiyah.id dan NU Online, media resmi Muhammadiyah dan Nahdlatul Ulama (NU). Permasalahannya adalah bagaimana bentuk-bentuk kontradiskursus makna jihad melalui suaramuhammadiyah.id dan NU Online? Tujuannya untuk menunjukkan bentuk-bentuk kontra-diskursus makna jihad melalui suaramuhammadiyah.id dan NU Online. Penelitian ini menggunakan metode analisis wacana kritis Norman Fairclough yang memfokuskan analisisnya pada tiga level: (1) analisis teks, (2) analisis praktik diskursus, dan (3) analisis sosio-kultural (konteks). Hasil penelitian menunjukkan bahwa bentuk kontra-diskursus radikalisme suaramuhammadiyah.id adalah merepresentasikannya sebagai jihad lil-muwajahah (bersungguh-sungguh menciptakan sesuatu yang unggul). Selain itu, NU Online menampilkan pemaknaan jihad kontekstual, seperti jihad melawan korupsi, melawan narkoba, melawan hoaks. Implikasi hasil penelitian ini menegaskan bahwa diskursus yang ditampilkan suaramuhammadiyah.id dan NU Online merupakan kontra-diskursus mengenai jihad sebagai perang atau kekerasan yang diwacanakan kelompok-kelompok muslim radikal. Kesimpulannya, media online suaramuhammadiyah.id dan NU Online memiliki peran strategis dalam menandingi dan melawan diskursus radikalisme, khususnya mengenai jihad sebagai perang dari kelompok-kelompok muslim radikal di Indonesia.
\end{abstract}

Kata Kunci: Kontradiskursus radikalisme, jihad, media online, suaramuhammadiyah.id, NU Online 


\section{PENDAHULUAN}

Pascareformasi tahun 1998 menjadi momentum titik balik kebangkitan kelompok muslimradikal di Indonesia. Kebangkitan kelompok muslim radikal pasca-Orde Baru ini disebut sebagai conservative turn, yakni titik balik kebangkitan kelompok muslim konservatif yang ditandai dengan pengambilalihan terhadap kelompok muslim mainstream karena pemikiranpemikiran liberal dan progresif di tubuh Muhammadiyah dan NU mulai ditolak. Termasuk kecenderungan di tubuh Majelis Ulama Indonesia (MUI) dalam beberapa dekade yang mulai menjadi lebih konservatif (Burhani, 2013; Ichwan, 2013; Van Bruinessen, 2013). Di sisi yang lain, kebangkitan kelompok muslim radikal juga ditandai dengan terlibatnya mereka dalam berbagai konflik antar-agama, munculnya kelompok-kelompok jihadis yang mengobarkan perang dan kekerasan, dan munculnya tindakan terorisme yang menyerang berbagai tempat, hotel, pariwisata, dan gereja di daerah-daerah di Indonesia (Van Bruinessen, 2013).

Pada saat yang sama, diskursus muslim radikal (radikalisme) juga berkembang secara dominan di ranah publik (Hasan, 2005). Mereka melakukan "dakwah publik" sebagai upaya islamisasi segala aspek kehidupan yang dipelopori oleh Partai Keadilan Sejahtera (PKS) (Fuad, 2015). Disebut radikalisme karena menurut Dawisha (Azra, 2016), mereka memiliki sikap jiwa yang membawa pada tindakan yang bertujuan melemahkan dan mengubah tatanan politik mapan dan menggantinya dengan sistem baru. Kelompok-kelompok Islamis (radikal) ini dengan semangat mewacanakan pemahaman mereka mengenai sistem pemerintahan, jihad, dan toleransi secara langsung maupun melalui media-media online yang mereka miliki, yang cenderung radikal. Mereka mewacanakan sistem pemerintahan khilafah, yakni sistem pemerintahan yang merujuk pada khulafaurrasyidin pasca wafatnya Rasulullah (Azra, 2016), sebagai pengganti demokrasi Pancasila, jihad sebagai perang atau tindak terorisme terhadap kaum kafir dan intoleransi terhadap nonmuslim.

Pada perkembangannya, seiring dengan pesatnya teknologi informasi dan komunikasi, gerakan-gerakan radikalisme juga mengubah strateginya dengan menggunakan semacam strategi baru, dengan tidak lagi hanya mengandalkan forum-forum publik, atau demonstrasi-demonstrasi turun ke jalan, tetapi mulai menggunakan media-media online dan media sosial sebagai alat perjuangannya. Mereka menyasar kalangan atau kelompok muda seperti mahasiswa di kampuskampus yang memang dekat dengan teknologi atau media baru ini (Afrianty, 2012). Mereka menjadikan media online sebagai ladang baru penyemaian benih-benih pemahaman radikal melalui diskursus yang mereka munculkan (Karman, 2015). Bahkan dalam perkembangannya, mereka juga menggunakan media-media sosial seperti Youtube, Twitter, Instagram, dan media-media baru lainnya sebagai media penyebaran pandangan-pandangan radikal (Muthohirin, 2015).

Diskursus radikalisme ini ditampilkan oleh media-media online yang berafiliasi kepada kelompok-kelompok muslim radikal seperti Jamaah Anshorut Tauhid (JAT), Majelis Mujahidin Indonesia (MMI), dan Hizbut Tahrir Indonesia (HTI). Melalui media-media online yang dimiliki, mereka mengonstruksi diskursus mengenai isu-isu seperti sistem pemerintahan, jihad, dan toleransi sesuai dengan pandangan dan kepentingan mereka. Pada isu sistem pemerintahan, mereka menolak sistem demokrasi, termasuk demokrasi Pancasila dan menggagas sistem pemerintahan khilafah yang berasaskan syariat Islam. Begitu pula pada isu jihad, dalam pandangan mereka jihad adalah memerangi orang-orang kafir sebagai musuh Islam dengan kekerasan dan terorisme. Termasuk mengenai toleransi yang dipandang sebagai akal-akalan kelompok-kelompok nonmuslim agar dapat menyingkirkan umat Islam (Afrianty, 2012; Karman, 2015; Muthohirin, 2015).

Diskursus radikalisme di media-media online tersebut memang dipengaruhi oleh pandanganpandangan kelompok-kelompok muslim radikal itu sendiri. Mengenai jihad, dalam pandangan 
kelompok-kelompok muslim yang berafiliasi dengan al-Qaeda seperti Majelis Mujahidin Indonesia (MMI), Jamaah Islamiyah (JI), dan Laskar Jihad (LJ), jihad dimaknai sebagai tindakan teror dan memerangi Amerika Serikat dan sekutu-sekutunya (Hasan, 2008). Sedangkan Hizbut Tahrir Indonesia (HTI) menafsirkan jihad sebagai upaya untuk memobilisasi semua kemampuan dalam perang demi Allah untuk menyebarkan pesan-pesan Islam (Azman, 2015). Dalam pandangan FPI, jihad adalah menghancurkan berbagai tempat kemaksiatan (Mubarak, 2007). FPI dikenal sangat konfrontatif dan cenderung mengedepankan kekerasan dalam memberantas segala kemaksiatan (Azra, 2016).

Diskursus radikalisme mengenai jihad sebagai teror di media online harus dilawan dengan diskursus antiradikalisme atau kontradiskursus radikalisme di ranah yang sama yakni media online. Maka dari itu peran media online dari kelompok-kelompok Islam moderat (washitiyah atau tengahan) seperti Muhammadiyah dan Nahdlatul Ulama (NU) menjadi sangat dibutuhkan untuk menandingi diskursus kelompok-kelompok muslim radikal, dengan memunculkan kontra-diskursus radikalisme mengenai jihad. Sebagaimana dikenal selama ini, Muhammadiyah dan NU merupakan organisasi Islam moderat di Indonesia dan menjadi kekuatan sipil Islam yang konsisten memperjuangkan tumbuhnya nilai-nilai demokrasi (Burhani, 2012; Hilmy, 2013; Nashir et al., 2019). Bahkan Muhammadiyah dan NU dapat dianggap sebagai warisan keagamaan dunia (Maman A. Majid Binfas et al., 2018). Meskipun Muhammadiyah dan NU secara historis dan kultur memang berbeda (Maman Abdul Majid Binfas et al., 2014), tetapi keduanya kini diklaim sebagai organisasi Islam moderat (wasithiyah). Muhammadiyah mengusung jargon Islam Berkemajuan dan NU mengibarkan slogan Islam Nusantara.

Media online suaramuhammadiyah.id dan NU Online merupakan media resmi organisasi Islam Muhammadiyah dan NU yang berfungsi sebagai semacam "corong" yang melantangkan suara-suara resmi dan kepentingan kedua organisasi Islam tersebut (Saputra \& Nazim, 2017; Sukmono \& Junaedi, 2020). Sebagai media resmi Muhammadiyah dan NU, keberadaannya tentu sangat strategis dalam konteks kontra-diskursus radikalisme. Satu sisi secara internal kedua berperan sebagai media yang memberikan pemahaman tentang nilai-nilai keislaman Muhammadiyah dan NU kepada masing-masing warganya, termasuk mengenai isu-isu radikalisme seperti dasar negara dan jihad. Di sisi lain secara eksternal, suaramuhammadiyah.id dan NU Online berperan sebagai alat untuk melawan pandangan-pandangan atau ajaran-ajaran yang dianggap menyimpang atau tidak sesuai dengan pandangan keislaman Muhammadiyah dan NU, termasuk melawan pandangan-pandangan radikalisme yang berkembang di Indonesia saat ini.

Berdasarkan latar belakang tersebut, permasalahan yang akan diteliti adalah bagaimana bentuk-bentuk kontra-diskursus radikalisme melalui media online suaramuhammadiyah.id dan NU Online? Selain itu, tujuan penelitian ini adalah menunjukkan adanya kontra-diskursus radikalisme melalui media online suaramuhammadiyah.id dan NU Online sebagai media online resmi organisasi Islam moderat Muhammadiyah dan NU.

\subsection{Kajian Penelitian Terdahulu}

Kajian mengenai kontra-diskursus radikalisme atau semacam kontraradikalisme dan deradikalisasi di berbagai jenis media online secara umum memang telah dilakukan oleh penelitipeneliti sebelumnya. Pertama, kajian oleh Taufiqur Rahman yang berjudul Contextualizing jihad and mainstream Muslim identity in Indonesia: the case of Republika Online (2017). Hasil kajian ini menunjukkan upaya kontra-diskursus melalui Republika online dengan mengkontekstualisasikan pemahaman makna jihad oleh kelompok muslim moderat di Indonesia, Muhammadiyah dan NU dengan menafsirkan jihad dengan makna non-kekerasan. Salah satu bentuk kontesktualisasi makna 
jihad sebagai upaya deradikalisasi adalah memaknai jihad dalam bentuk pemberdayaan komunitas muslim di bidang pendidikan dan ekonomi melalui organisasi-organisasi Islam seperti Muhammadiyah dan NU (Rahman, 2017).

Kedua, studi yang dilakukan oleh Muhammad Nurrohman yang berjudul Analisis isi media NU online tentang radikalisme (2019), yang menunjukkan adanya konten yang melakukan perlawanan terhadap radikalisme, salah satunya seperti yang dipublikasikan di NU Online. NU Online menjadi salah satu media online yang tidak setuju dengan gagasan radikalisme. Alasan tersebut diperkuat dengan adanya tujuh artikel dan berita di website www.nu.or.id. (Nurrohman, 2019).

Ketiga, studi yang dilakukan oleh Riyan Fadli tentang Kontra Radikalisme Agama di Dunia Maya (2019). Hasil kajian ini menunjukkan bahwa kontra-radikalisme agama yang dilakukan lewat portal online memiliki intensitas yang cukup tinggi dilakukan oleh Dutaislam.com dalam melakukan kontra radikalisme agama, sedangkan Sangpencerah.id menjadi portal online yang tidak produktif. Dalam postingan Nu.or.id postingannya masih normatif dalam hal kontra radikalisme agama dan lebih banyak menampilkan berita acara. Nu.or.id lebih banyak melakukan pembelaan terhadap persoalan yang berhubungan dengan NU, redaksi lebih banyak melakukan kontra radikalisme secara umum, tidak spesifik membahas isu radikal (Fadli, 2019).

Keempat, studi oleh Yani Tri Wijayanti yang berjudul Radicalism Prevention through Propaganda Awareness on Social Media (2020). Hasil kajian menunjukkan bahwa propaganda awareness penting dilakukan karena mampu meningkatkan kesadaran terhadap informasi-informasi yang mengandung radikalisme yang disebarkan melalu media sosial sehingga mampu menyegah sekaligus melindungi siswa dari paparan radikalisme (Wijayanti, 2020).

Kelima, kajian yang dilakukan oleh Sefriyono mengenai Jihad Digital: Pembingkaian Narasi Kontra Radikalisasi NU Online di Dunia Maya (2020). Hasil studi menunjukkan bahwa NU Online mendiagnosis, narasi-narasi radikalisasi dan intoleran di dunia maya merupakan sumber kegaduhan ideologi bangsa dan disharmoni hubungan antar agama. Dalam strategi prognosisnya, NU Online mengembangkan narasi-narasi seperti Islam sangat sesuai dengan Pancasila. Sementara dalam strategi motivasi, NU Online mengajak semua elemen bangsa untuk mempertahankan integrasi bangsa dengan penerbitan headline seperti "empat alasan penolakan khilafah" (Sefriyono, 2020).

Kajian-kajian di atas menunjukkan bahwa media online atau media yang berbasis internet (internet based) menjadi medium baru kelompok-kelompok muslim radikal untuk menyebarluaskan pandangan ideologis mereka. Kelompok-kelompok muslim radikal menggunakan internet sebagai medium yang efektif dan efisien menjadikan radikalisme dan fundamentalisme sebagai isu global (Khatib, 2019).

Di sisi lain, penelitian-penelitian di atas juga menunjukkan adanya perlawanan atau upayaupaya deradikalisasi oleh media-media online tertentu. Meskipun demikian, kajian yang secara khusus mengenai peran media online milik Muhammadiyah dan NU, yakni suaramuhammadiyah.id dan NU Online dalam melawan radikalisme belum banyak dilakukan. Sebagai media resmi yang dimiliki oleh dua organisasi Islam terbesar di Indonesia, semestinya kajian mengenai peran kedua media online tersebut dalam mencegah radikalisme banyak dilakukan. Maka dari itu, penelitian ini berupaya menunjukkan peran kedua media online resmi organisasi Islam terbesar di Indonesia ini dalam pencegahan radikalisme dalam bentuk kontra-diskursus, khususnya mengenai jihad yang ditampilkan dalam kedua media online tersebut. 


\subsection{Kerangka Konseptual}

Penelitian ini menggunakan teori atau konsep mengenai diskursus sebagai landasan teoritisnya. Istilah diskursus atau wacana dipopulerkan oleh Michel Foucault. Diskursus merupakan keseluruhan domain (bidang) yang mana bahasa digunakan dengan pola-pola tertentu. Diskursus dapat diartikan sebagai keseluruhan wilayah konseptual karena pengetahuan diciptakan atau dibentuk dan diproduksi (Lubis, 2014). Istilah diskursus dapat digunakan dalam konteks yang luas dan dipakai untuk beberapa disiplin. Diskursus meliputi dua bidang, pertama dalam studi bahasa. Diskursus dapat dipahami dalam bentuk interaksi dan tindakan sosial antarindividu yang berinteraksi bersama-sama dalam sebuah situasi sosial. Kedua, diskursus dapat juga dipakai di dalam kajian post-strukturalis sebagai konstruksi realitas sosial (Fairclough, 1995, 2013).

Diskursus juga dapat dilihat sebagai relasi pada komunikasi antara orang-orang dalam bentuk berbicara, menulis, dan cara-cara komunikasi yang lain, dan menjelaskan juga relasi antara peristiwa-peristiwa komunikatif (percakapan, surat kabar, artikel) (Fairclough, 2010). Diskursus dalam kaitannya dengan pemahaman terhadap teks adalah setiap bahasa yang dibakukan lewat tulisan, maka diskursus selalu berkaitan dengan bahasa yang digunakan. Bahasa dalam diskursus dianggap sebagai peristiwa (event), yakni bahasa yang membincangkan sesuatu (Ricoeur, 2006). Jadi, diskursus adalah bahasa ketika ia digunakan untuk berkomunikasi.

Adapun kontra-diskursus adalah semacam perlawanan dengan memproduksi diskursus tandingan. Bila diskursus merujuk pada dunia yang digambarkan, yang diungkapkan, dan yang diinterpretasikan (Ricoeur, 2006), begitu juga dengan kontra-diskursus. Akan tetapi, dalam kontradiskursus apa yang digambarkan dan diinterpresikan berbeda dengan apa yang digambarkan dan diinterpresikan dalam diskursus. Sebagai contoh, istilah Occidentalism sebagai kontra-diskursus istilah orientalisme, atau dalam posisi biner seperti West-East, Self-Other, Oppressed-Oppressor (Sorensen \& Chen, 1996). Kontra-diskursus juga dapat berbentuk, misalnya, istilah post-colonial sebagai kontra-diskursus kolonialisme dan imperialisme (Tiffin, 1987). Dalam pandangan Foucault kontra-diskursus berkaitan dengan kelompok yang sebelumnya tidak bersuara kemudian mulai mengartikulasikan keinginan mereka untuk melawan dominasi wacana otoritatif yang berlaku (Moussa \& Scapp, 1996).

Kontra-diskursus radikalisme dalam konteks ini dilakukan di media baru. Media baru adalah media yang berbasis pada internet. Teknologi yang menyediakan konvergensi, jaringan digital, jangkauan global, interaktifitas, komunikasi many-to-many, dan bentuk-bentuk media yang seseorang dapat menjadi produser sekaligus konsumer (Flew, 2005). Media baru sebenarnya mengacu pada perubahan-perubahan yang luas dalam produksi media, distribusi, dan penggunaannya, terutama yang berkaitan dengan digitalisasi dan konvergensi (Flew, 2005; McQuail, 2010). Media baru diidentikkan dengan digital, interaktif, hipertekstual, virtual, jaringan, dan simulasi (Lister et al., 2009). Karakteristik media baru yang membedakannya dengan media lama atau konvensional adalah interaktifitas, presentasi sosial, pengayaan media, otonomi, penuh kesenangan, privasi, dan personalisasi (McQuail, 2010). Dalam konteks penelitian ini, media baru tersebut adalah suaramuhammadiyah.id dan NU Online.

\section{METODE PENELITIAN}

Penelitian ini menggunakan metode Critical Discourse Analysis (CDA) model Norman Fairclough yang memusatkan perhatian pada bahasa sebagai praktik kekuasaan, karena bahasa terbentuk dan dibentuk dari relasi dan konteks sosial tertentu. Analisis Wacana Kritis Fairclough ini relevan dengan permasalahan penelitian, dan juga karena metode yang disebut model "perubahan sosial" ini mengintegrasikan analisis linguistik dengan pemikiran sosial dan politik 
sehingga analisisnya lebih komprehensif. Analisis wacana kritis Fairclough memiliki tiga dimensi analisis, yakni teks, praktik diskursus (discourse practice), dan praktik sosiokultural (Fairclough, 1995).

Media online yang diteliti adalah media resmi Muhammadiyah dan NU, yakni suaramuhammadiyah.id dan NU Online karena selain keduanya berbasis internet, kedua media online ini merupakan media resmi dan menjadi representasi Muhammadiyah dan NU yang berfungsi sebagai semacam "corong" yang melantangkan suara-suara resmi dan kepentingan kedua organisasi Islam tersebut (Saputra \& Nazim, 2017; Sukmono \& Junaedi, 2020). Rentang waktu yang dipilih adalah selama lima tahun, yakni mulai Januari 2016 sampai Desember 2020. Adapun unit analisisnya adalah berita, artikel, opini, dan tajuk. Narasumbernya adalah redaktur suaramuhammadiyah.id, redaktur NU Online, dan dilengkapi narasumber dari tokoh-tokoh Muhammadiyah dan NU.

Metode pengumpulan data penelitian ini adalah dokumentasi, wawancara mendalam, dan kajian Pustaka. Untuk metode analisis data penelitian ini menggunakan tiga level analisis mengikuti model Analisis Wacana Kritis Fairclough, yaitu analisis teks, analisis praktik diskursus, dan analisis sosio-kuktural. Analisis teks dilakukan dengan analisis critical linguistic untuk memahami aspek-aspek semantik yang digunakan di media online. Analisis praktik diskursus meliputi produksi teks dan konsumsi teks yang diperoleh melalui wawancara mendalam dengan narasumber untuk memahami proses pembuatan teks dan konsumsi teks. Analisis praktik sosiokultural mengaitkan antara teks, praktik diskursus dengan konteks atau kondisi sosiokultural yang terjadi saat teks disusun untuk memahami konteks kontra-diskursus radikalisme saat ini.

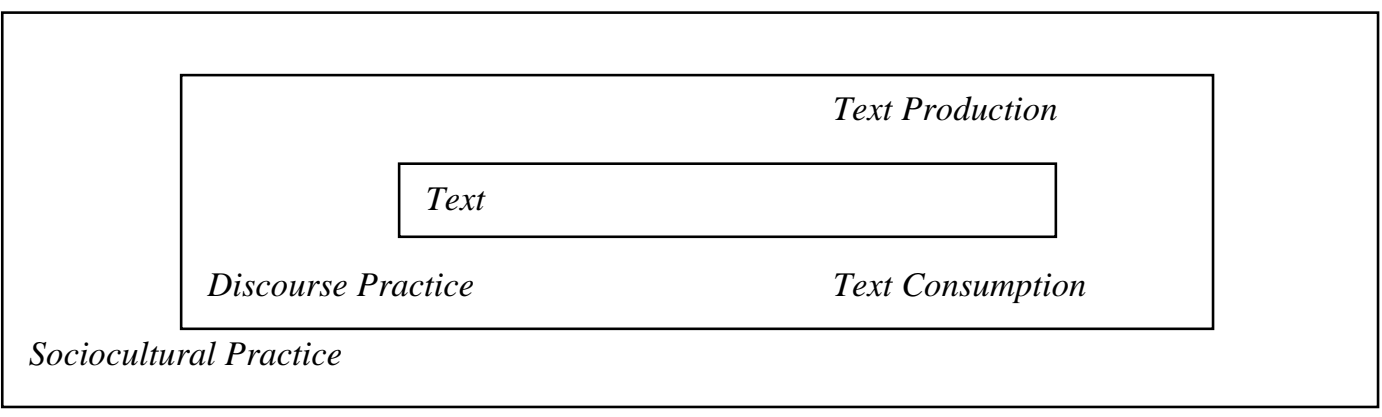

Sumber: Fairclough, 1995

Gambar 1. Dimensi Analisis Wacana Kritis Norman Fairclough

\section{HASIL DAN PEMBAHASAN}

\subsection{Hasil}

a. Analisis Teks Kontra-Diskursus Radikalisme mengenai Jihad

Dalam analisis teks ini terdapat tiga elemen yang dianalisis, yaitu representasi, relasi, dan identitas. Pertama, representasi. Representasi merujuk pada bagaimana gagasan atau ide mengenai kontra-diskursus radikalisme tentang jihad ditampilkan dan digambarkan dalam isi media online suaramuhammadiyah.id dan NU Online.

Representasi suaramuhammadiyah.id. Sebagai media resmi organisasi Islam Muhammadiyah yang berkemajuan, suaramuhammadiyah.id sama sekali tidak menampilkan diskursus jihad sebagai kekerasan, perang, apalagi terorisme. Suaramuhammadiyah.id justru banyak menampilkan makna-makna jihad lain yang lebih kontekstual di Indonesia sebagai kontradiskursus radikalisme mengenai isu jihad ini. Secara khusus suaramuhammadiyah.id merepresentasikan makna jihad sebagai perjuangan menghadapi sesuatu (jihad lil-muwajahah) dalam wujud memberikan jawaban-jawaban alternatif yang terbaik untuk mewujudkan kehidupan 
yang lebih utama. Representasi jihad lil-muwajahah sebagai bingkai utama kontra-diskursus radikalisme ditampilkan suaramuhammadiyah.id pada judul "Haedar Nashir: Bergerak Dari Jihad Lil-Muaradhah Ke Jihad Lil-Muwajahah" (02/07/2017)".

Representasi jihad lil-muwajahah sebagai kontra-diskursus radikalisme kemudian dijabarkan dan diimplementasikan dalam makna-makna jihad yang lebih kontekstual untuk menjawab permasalahan-permasalahan umat. Makna-makna jihad kontekstual yang direpresentasikan suaramuhammadiyah.id sebagai kontra-diskursus radikalisme di antaranya adalah jihad konstitusi, jihad antikorupsi, jihad ekonomi, jihad politik, jihad literasi, jihad sosial, dan jihad melawan Covid19. Artikel-artikel dan berita-berita suaramuhammadiyah.id yang menampilkan dan menggambarkan makna-makna jihad sebagai kontra-diskursus radikalisme di antaranya adalah "Ketua Komisi Yudisial: Jihad Konstitusi Sebagai Jalan Muhammadiyah Mewujudkan Keadilan Sosial" (10/02/2017), "SATGAS Muda Siapkan Motivator Jihad Anti Korupsi" (12/01/2016), "Ketum PP Aisyiyah: Jihad Ekonomi Jadi Agenda Strategis Aisyiyah Makmurkan Bangsa" (20/01/2018), "Prof Zainudddin Maliki: Jihad Politik Salah Satunya Untuk Perbaiki Sulaman Negeri” (26/12/2018), “Launching 'Taman Pustaka 38', IMM Makassar Timur Gelorakan Jihad Literasi" (29/092018), "Muhammadiyah Dan 'Aisyiyah Provinsi Riau Lakukan Jihad Sosial Lawan Tuberculosis" (28/08/2017), dan "Haedar Nashir: Membantu Dhuafa Melawan Wabah Corona Jihad Fisabilillah" (07/05/2020).

Representasi NU Online. Sebagai media resmi dari organisasi Islam NU yang moderat, NU Online merepresentasikan makna jihad alih-alih sebagai tindak kekerasan, perang, dan terorisme, tetapi justru menegaskan penolakannya terhadap makna-makna jihad tersebut. Penentangan NU Online terhadap makna jihad sebagai kekerasan dan perang dimunculkan oleh NU Online pada artikel-artikel berikut, "Makna Resolusi Jihad Bukan Lagi dengan Angkat Senjata" (24/10/2018), "KH Yusuf Chudlori: Jihad Tidak Selalu Bermakna Perang" (26/01/2019), "Ke Suriah atas Nama Jihad? Syekh Taufiq Al-Buthi: Mereka Tidak Mengerti Islam" (13/03/2019), dan "Soal Ekstremisme dan Salah Paham Memaknai Jihad Soal Ekstremisme dan Salah Paham Memaknai Jihad" (14/11/2019).

Sebaliknya, NU Online banyak menampilkan dan menggambarkan makna jihad secara lebih konstekstual sebagai kontra-diskursus radikalisme. Makna-makna jihad yang direpresentasikan NU Online untuk menandingi diskursus makna jihad sebagai tindak kekerasan, perang, dan terorisme di antaranya adalah jihad melawan narkoba, jihad media sosial (melawan hoaks), jihad antikorupsi, jihad melawan kemiskinan dan kebodohan, jihad lingkungan hidup, jihad budaya, ekonomi, dan pendidikan, serta jihad menjaga perbatasan.

Makna-makna jihad kontekstual sebagai kontra-diskursus radikalisme di atas direpresentasikan oleh NU Online dalam artikel-artikel atau berita-berita berikut: "Ansor Surabaya Kumandangkan Jihad Lawan Narkoba” (05/09/2017), "Kumpulkan Kiai dan Nyai, PSP Perkuat Jihad Lawan Radikalisme Berbasis Medsos" (29/06/2018), "Jihad Lawan Hoaks, Ketua PCNU Pringsewu Ajak 'Klik' NU Online " (22/03/2018), "Ingin Jihad? Ketua PBNU: Mari Lawan Korupsi" (24/04/2019), "Jihad saat Ini Perangi Kemiskinan, Kebodohan, dan Keterbelakangan" (24/08/2019), "Mengurangi Limbah Plastik, Jihad yang Butuh Dukungan Semua Pihak" (26/06/2019), “Jihad Itu di Bidang Ekonomi, Budaya, dan Pendidikan, Bukan Ngebom!" (21/01/2016), dan “Gus Tutut: Jaga Perbatasan Bagian dari Jihad” (18/08/2016).

Kedua adalah relasi. Relasi berkaitan dengan hubungan antar partisipan, yakni pembuat teks (wartawan atau redaktur), khalayak pembaca, dan partisipan publik (politisi, tokoh, ulama, dan sebagainya) ditampilkan dan digambarkan dalam teks. Dalam konteks ini, partisipan atau pihakpihak yang berelasi dalam teks adalah (1) wartawan/redaktur suaramuhammadiyah.id dan NU Online, (2) pembaca/warga Muhammadiyah dan NU, dan (3) kelompok-kelompok muslim radikal. 
Relasi suaramuhammadiyah.id. Relasi suaramuhammadiyah.id dengan organisasi Muhammadiyah adalah sebagai corong yang menyuarakan pandangan-pandangan Muhammadiyah sebagai organisasi Islam Berkemajuan. Maka dari itu, dalam konteks kontra-diskursus radikalisme mengenai jihad, suaramuhammadiyah.id merepresentasikan pandangan-pandangan Muhammadiyah mengenai makna jihad. Hal ini karena wartawan dan redaktur suaramuhammadiyah.id adalah warga dan pimpinan Muhammadiyah. Mengenai suaramuhammadiyah.id yang membawa kepentingan Muhammadiyah dalam upaya kontra-diskursus radikalisme mengenai jihad ditampilkan oleh suara muhammadiyah dalam artikel berikut: "Jihad Pergerakan Muhammadiyah" (16/07/2020), dan "Haedar Nashir: Bergerak Dari Jihad Lil-Muaradhah Ke Jihad LilMuwajahah” (02/07/2017).

Relasi suaramuhammadiyah.id dengan pembacanya dapat dikatakan sebagai relasi yang simetris atau sekubu dalam konteks kontra-diskursus radikalisme mengenai jihad. Pembaca suaramuhammadiyah.id sebagian besar adalah warga Muhammadiyah yang memiliki kesamaan pandangan baik dengan Organisasi Muhammadiyah maupun dengan suaramuhammadiyah.id. Mereka sama-sama memaknai jihad bukan sebagai kekerasan atau peperangan, tetapi jihad sebagai upaya yang sungguh-sungguh untuk menciptakan sesuatu yang unggul. Relasi suaramuhammadiyah.id dan pembacanya dalam konteks pemahaman yang sama mengenai makna jihad sebagai kontra-diskursus radikalisme dapat dilihat pada berita-berita berikut: "Ingin Indonesia Berdaulat, MPM Gelorakan Jihad Kedaulatan Pangan" (30/12/2016), "Berantas TB Bagi Kader 'Aisyiyah Adalah Jihad Sosial" (21/09/2018), dan "Launching 'Taman Pustaka 38', IMM Makassar Timur Gelorakan Jihad Literasi” (29/09/2018).

Relasi suaramuhammadiyah.id dengan kelompok-kelompok muslim radikal dalam konteks pemaknaan jihad tentu saja saling berlawanan atau asimetris. Suaramuhammadiyah.id dan pembacanya lebih memaknai jihad sebagai upaya sungguh-sungguh menciptakan sesuatu yang unggul dan diwujudkan dalam berbagai bentuk tindakan. Sebaliknya, kelompok-kelompok muslim radikal lebih memaknai jihad sebagai tindak kekerasan, peperangan, dan bahkan terorisme. Relasi suaramuhammadiyah.id dengan kelompok-kelompok muslim radikal dalam konteks kontradiskursus radikalisme ditampilkan oleh suaramuhammadiyah.id dalam berita-berita berikut. "Memahami Perang Atas Nama Jihad" (06/05/2016), "Jihad Perang Dan Jihad Damai" (25/02/2019), dan "Prof Muhadjir Effendy: Jihadis Memang Doktrin Islam” (26/08/2016).

Relasi NU Online. Relasi NU Online dengan organisasi NU adalah dalam posisi yang sama karena keduanya menolak pandangan yang kelompok-kelompok yang memaknai jihad sebagai kekerasan, peperangan, dan terorisme. NU Online mendukung NU dalam memaknai jihad secara lebih damai dan kontekstual dengan situasi di Indonesia yang diwujudkan dalam berbagai bentuk jihad, seperti jihad antinarkoba, jihad melawan hoaks, jihad antikorupsi, dan jihad-jihad damai lainnya. Relasi NU Online dengan organisasi NU yang sejiwa dalam memandang makna jihad sebagai kontra-diskursus radikalisme adalah karena sebagian besar wartawan dan redaktur NU Online adalah anggota dan pengurus NU yang memiliki nilai-nilai Aswaja yang kuat. Relasi yang sekufu antara NU Online dan organisasi NU dalam konteks kontra-diskursus radikalisme mengenai jihad ditampilkan oleh NU Online dalam artikel-artikel dan berita-berita berikut: "Kiai Said Jelaskan Empat Macam Jihad" (23/10/2017), “Trilogi Jihad Zaman Now” (24/05/2018), "Makna Resolusi Jihad Bukan Lagi dengan Angkat Senjata" (24/10/2018), "Ketua NU Jateng: Nasionalisme dan Patriotisme adalah Jihad Aswaja" (25/06/2019).

Relasi NU Online dengan pembacanya dapat dipastikan bersifat simetris juga karena sebagian besar pembaca NU Online adalah Nahdliyin yang mengikuti paham Aswaja. Dalam konteks kontradiskursus radikalisme mengenai jihad, NU Online dan pembaca berada dalam satu pihak yang menentang pemaknaan jihad sebagai tindak kekerasan, peperangan, dan terorisme sebagaimana 
seringkali diwacanakan dan dipraktikkan oleh kelompok-kelompok muslim radikal. Relasi NU Online dengan pembacanya yang lebih memaknai jihad secara lebih kontekstual dimunculkan oleh NU Online dalam artikel-artikel dan berita-berita di antaranya berikut ini. "Warga Lakardowo Jihad Melawan Limbah PT. PRIA" (06/12/2019), "Kumpulkan Kiai dan Nyai, PSP Perkuat Jihad Lawan Radikalisme Berbasis Medsos" (26/09/2018), "Jihad Lawan Hoaks, Ketua PCNU Pringsewu Ajak 'Klik' NU Online ” (22/03/2018), “Bersama Pergunu, Santri Al-Karimiyah Depok Galakkan Jihad Pena" (06/10/2018), dan "Ketua Ansor Jateng: Pemudik adalah Jihad fi Sabilillah" (11/06/2018).

Relasi NU Online dengan kelompok-kelompok muslim radikal adalah memposisikannya sebagai lawan yang berseberangan dalam konteks kontra-diskursus radikalisme mengenai jihad. NU Online dan pembacanya (Nahdliyin) memandang jihad secara kontekstual dengan berbagai wujudnya seperti jihad antinarkoba, jihad antikorupsi, jihad antihoaks, jihad ekonomi, dan sebagainya. Sementara kelompok-kelompok muslim radikal lebih memaknai jihad dalam bentuk kekerasan dan peperangan. Relasi NU Online dengan kelompok-kelompok muslim radikal ditampilkan oleh NU Online dalam artikel-artikel dan berita-berita di antaranya sebagai berikut: "Soal Ekstremisme dan Salah Paham Memaknai Jihad" (14/11/2019), "Ke Suriah atas Nama Jihad? Syekh Taufiq Al-Buthi: Mereka Tidak Mengerti Islam" (13/03/2019), "KH Yusuf Chudlori: Jihad Tidak Selalu Bermakna Perang” (06/01/2019).

Ketiga, identitas. Identitas dalam analisis teks ini berkaitan dengan identitas partisipan, yakni pembuat teks (wartawan atau redaktur), khalayak pembaca, dan partisipan publik (politisi, tokoh, ulama, dan sebagainya) ditampilkan dan digambarkan dalam teks, termasuk bagaimana pembuat teks mengidentifikasikan dirinya dalam wacana yang ditampilkan oleh suaramuhammadiyah.id dan NU Online dalam teks masing-masing.

Identitas suaramuhammadiyah.id. Dalam konteks kontra-diskursus radikalisme mengenai jihad, suaramuhammadiyah.id menyebutkan identitas Muhammadiyah sebagai gerakan dakwah dan tajdid (dalam judul: Jihad Pergerakan Muhammadiyah, 16/07/2020), dan organisasi berkemajuan (dalam judul: Haedar Nashir: Bergerak Dari Jihad Lil-Muaradhah Ke Jihad Lil-Muwajahah, 02/07/2017). Suaramuhammadiyah.id tidak menyebut secara eksplisit identitasnya dalam konteks kontra-diskursus radikalisme mengenai jihad. Meskipun demikian, sebagai media resmi Muhammadiyah, identitas Muhammadiyah sebagai gerakan dakwah dan tajdid, serta berkemajuan dapat dilekatkan juga sebagai identitas suaramuhammadiyah.id. Selain itu, pelekatan identitas suaramuhammadiyah.id dalam identitas Muhammadiyah karena sebagian besar wartawan dan redaktur suaramuhammadiyah.id adalah anggota dan pimpinan Muhammadiyah yang berpola pikir berkemajuan dan memiliki perspektif dakwah dan tajdid juga.

Identitas pembaca suaramuhammadiyah.id pun tidak disebutkan secara eksplisit oleh suaramuhammadiyah.id, meskipun dapat diidentifikasi bahwa pembaca suaramuhammadiyah.id sebagian besar adalah warga Muhammadiyah. Identitas pembaca suaramuhammadiyah.id dapat diidentikkan juga dengan Muhammadiyah sebagai organisasinya, yakni berkemajuan, bertajdid, dan berdakwah. Berkemajuan berarti berpikir maju, termasuk dalam memahami makna jihad yang tidak lagi sebagai peperangan, tetapi menciptakan suatu alternatif yang unggul. Pandanganpandangan jihad yang berkemajuan sebagai identitas pembacanya ditampilkan oleh suaramuhammadiyah.id dalam berita-berita dan artikel-artikel di antaranya berikut ini. "Prof Zainudddin Maliki: Jihad Politik Salah Satunya Untuk Perbaiki Sulaman Negeri” (26/12/2018), "Ketua Komisi Yudisial: Jihad Konstitusi Sebagai Jalan Muhammadiyah Mewujudkan Keadilan Sosial" (10/02/2017), "Ketum PP Aisyiyah: Jihad Ekonomi Jadi Agenda Strategis Aisyiyah Makmurkan Bangsa" (20/01/2018), dan "Okky Madasari: Sastra Sebagai Jihad Anti Korupsi" $(10 / 12 / 2020)$. 
Identitas kelompok-kelompok muslim radikal ditampilkan dan digambarkan oleh suaramuhammadiyah.id sebagai jihadis, dan sekelompok orang yang mengatasnamakan Tuhan sebagai identitasnya. Dalam berita yang berjudul "Prof Muhadjir Effendy: Jihadis Memang Doktrin Islam" (02/06/2018) dituliskan bahwa "Jihadis memang doktrin Islam. Nggak perlu mengelak, jika jihad memang ajaran Islam untuk berjuang menuju puncak kejayaan, kata Prof Dr Muhadjir Effendy yang juga Menteri Pendidikan dan Kebudayaan (Mendikbud) dalam Khutbah Jum'at (26/8/16) di Masjid Gede Yogyakarta. Sedangkan identitas sebagai sekelompok orang yang mengatasnamakan Tuhan terdapat pada judul "Memahami Perang Atas Nama Jihad" $(06 / 05 / 2016)$.

Identitas NU Online. Organisasi NU merupakan organisasi Islam yang berpaham Ahlussunnah wal Jamaah (Aswaja) yang moderat dan toleran. Maka dari itu, dalam memaknai jihad NU juga merujuk pada nilai-nilai Aswaja yang anti-kekerasan dan penuh toleransi, yang disebut sebagai jihad Aswaja (dalam judul: "Ketua NU Jateng: Nasionalisme dan Patriotisme adalah Jihad Aswaja”, 25/06/2019).

Mengenai identitas NU Online sebagai media resmi NU dalam konteks kontra-diskursus radikalisme mengenai jihad, secara eksplisit memang tidak disebutkan. Akan tetapi, fungsi dan peran NU Online sebagai media jihad warga NU sangat vital, terutama jihad melawan hoaks atau berita bohong, sebagaimana yang ditampilkan dalam judul, "Jihad Lawan Hoaks, Ketua PCNU Pringsewu Ajak 'Klik' NU Online" (22/03/2018). Meskipun demikian, identitas NU Online dapat disandingkan dengan identitas NU yang berpaham Aswaja yang moderat dan toleran sehingga dalam memaknai jihad pun adalah jihad yang sesuai dengan nilai-nilai Aswaja, seperti jihad antikorupsi, jihad melawan hoaks, jihad melawan narkoba, jihad peduli lingkungan, dan makna-makna jihad kontekstual lainnya. Sebagaimana ditampilkan oleh NU Online dalam berita-berita dan artikel-artikel berikut ini: "Ingin Jihad? Ketua PBNU: Mari Lawan Korupsi”" (24/04/2019), "Jihad Zaman Now Juga Merambah Dunia Maya” (26/08/2019), “Ansor Surabaya Kumandangkan Jihad Lawan Narkoba" (05/09/2017), dan "Mengurangi Limbah Plastik, Jihad yang Butuh Dukungan Semua Pihak" (26/06/2019).

Identitas pembaca NU Online tidak secara jelas disebutkan dalam pemberitaanpemberitaannya mengenai kontra-diskursus radikalisme jihad. Meskipun demikian, karena sebagian besar pembaca NU Online adalah Nahdliyin, identitas NU sebagai organisasi Islam yang berpaham Aswaja dapat juga disematkan pada identitas pembaca NU Online. Paham Aswaja yang bersifat moderat dan toleran menjadikan pemahaman pembaca NU Online dalam memahami makna jihad juga lebih moderat dan antikekerasan. Dalam pemaknaan pembaca NU, jihak bukanlah tindak kekerasan, peperangan, dan terorisme, tetapi jihad damai dan kontekstual. Pemahaman jihad pembaca NU Online yang sesuai dengan doktrin Aswaja ditampilkan oleh NU Online di antarannya dalam berita-berita dan artikel-artikel berikut: "Tugas Santri Gelorakan Ruhul Jihad untuk Menjawab Tantangan Zaman” (26/10/2020), “Tak Cukup Kuasai Pengetahuan Agama, Santri Perlu Jihad di Medsos" (14/10/2019), "Rijalul Ansor Jakarta Timur Siap Jihad Lawan Hoaks" (28/03/2018), "Ansor Surabaya Kumandangkan Jihad Lawan Narkoba" (05/09/2017), dan “Gus Tutut: Jaga Perbatasan Bagian dari Jihad” (18/08/2016).

Identitas kelompok-kelompok muslim radikal dalam konteks kontra-diskursus radikalisme mengenai isu jihad ditampilkan dan digambarkan sebagai jihadis ekstrem atau kelompok ekstrem sebagai identitasnya. Identitas ini berbeda dengan identitas pembaca NU Online karena jihadis ekstrem ini melakukan bom bunuh diri atas nama jihad. Identitas jihadis ekstrem ini ditampilkan dan digambarkan oleh NU Online dalam berita yang berjudul "Soal Ekstremisme dan Salah Paham Memaknai Jihad" (14/11/2019). 
Tabel 1. Analisis Teks suaramuhammadiyah.id dan NU Online sebagai Kontra-Diskursus Radikalisme dalam Isu Jihad

\begin{tabular}{|c|c|c|}
\hline \multirow{2}{*}{$\begin{array}{l}\text { Elemen } \\
\text { Analisis Teks }\end{array}$} & \multicolumn{2}{|c|}{ Media Online } \\
\hline & Suaramuhammadiyah.id & NU Online \\
\hline Representasi & $\begin{array}{l}\text { Makna jihad sebagai jihal lil-muwajahah } \\
\text { (berjuang menghadapi sesuatu untuk } \\
\text { menciptakan sesuatu yang unggul) yang } \\
\text { diwujudkan dalam bentuk jihad konstitusi, } \\
\text { jihad antikorupsi, jihad ekonomi, jihad } \\
\text { politik, jihad literasi, jihad sosial, dan jihad } \\
\text { melawan Covid-19. }\end{array}$ & $\begin{array}{l}\text { Menentang makna jihad sebagai tindak } \\
\text { kekerasan, perang, dan terorisme, serta } \\
\text { menggambarkan jihad secara lebih } \\
\text { kontekstual dengan situasi di Indonesia } \\
\text { seperti jihad melawan narkoba, jihad media } \\
\text { sosial (melawan hoaks), jihad antikorupsi, } \\
\text { jihad lingkungan hidup, dan sebagainya. }\end{array}$ \\
\hline Relasi & $\begin{array}{l}\text { Relasi suaramuhammadiyah.id dengan } \\
\text { organisasi Muhammadiyah dan } \\
\text { pembacanya lebih bersifat simetris atau } \\
\text { sekubu yang memandang jihad sebagai } \\
\text { jihad lil-muwajahah, daripada jihad } \\
\text { kekerasan, peperangan, dan terorisme. } \\
\text { Relasi suaramuhammadiyah.id dengan } \\
\text { kelompok-kelompok muslim radikal } \\
\text { adalah asimetris atau berlawanan karena } \\
\text { pemahaman yang berbeda mengenai jihad. }\end{array}$ & $\begin{array}{l}\text { Relasi NU Online dengan organisasi NU dan } \\
\text { pembacanya (Nahdliyin) adalah sekufu, yang } \\
\text { memaknai jihad secara lebih kontekstual dan } \\
\text { menentang pemaknaan jihad kekerasan, } \\
\text { peperangan, dan terorisme. } \\
\text { Relasi NU Online dengan kelompok- } \\
\text { kelompok muslim radikal adalah berlawanan } \\
\text { karena pemaknaan yang berbeda mengenai } \\
\text { jihad. }\end{array}$ \\
\hline Identitas & $\begin{array}{l}\text { Identitas suaramuhammadiyah.id sama } \\
\text { dengan identitas Muhammadiyah sebagai } \\
\text { organisasi Islam Berkemajuan. } \\
\text { Identitas pembaca suaramuhammadiyah.id } \\
\text { juga berpaham Islam Berkemajuan. } \\
\text { Identitas kelompok-kelompok muslim } \\
\text { radikal adalah jihadis yang } \\
\text { mengatasnamakan Tuhan. }\end{array}$ & $\begin{array}{l}\text { Identitas NU Online mengikuti atau sama } \\
\text { dengan identitas NU sebagai organisasi Islam } \\
\text { berpaham Aswaja. } \\
\text { Identitas pembaca NU Online juga berpaham } \\
\text { Aswaja karena mereka adalah Nahdliyin. } \\
\text { Identitas kelompok-kelompok muslim radikal } \\
\text { adalah jihadis ekstrem atau kelompok } \\
\text { ekstrem. }\end{array}$ \\
\hline
\end{tabular}

Sumber: diolah dari hasil penelitian.

\section{b. Analisis Praktik Diskursus}

Analisis praktik diskursus (discourse practice) merupakan dimensi yang berhubungan dengan proses penelaahan produksi teks dan konsumsi teks. Dalam analisis ini dikaji mengenai bagaimana produksi dan konsumsi teks-teks kontra-diskursus radikalisme mengenai jihad di suaramuhammadiyah.id dan NU Online?

Produksi teks suaramuhammadiyah.id. sebagai media resmi organisasi Muhammadiyah, suaramuhammadiyah.id memiliki visi "Menjadi Media Utama Muhammadiyah dan Islam di Indonesia". Menurut Rizki Putra Dewantoro, Managing Editor dan Reporter suaramuhammadiyah.id, misi atau tujuan suaramuhammadiyah.id adalah (1) merekam denyut Muhammadiyah, (2) memperkenalkan profil dan kontribusi Muhammadiyah pada masyarakat dunia, (3) menyebarkan syiar Islam Berkemajuan, dan (4) mendorong produktivitas dan kreativitas kajian tentang Muhammadiyah dan Islam (Wawancara dengan Peneliti melalui WhatsApp (WA), 1 September 2021).

Fungsi dan posisi suaramuhammadiyah.id bagi Muhammadiyah dan warga Muhammadiyah adalah sebagai sayap media resmi Pimpinan Pusat Muhammadiyah (Majalah Suara Muhammadiyah) untuk menyebarkan syiar Islam Berkemajuan. Maka dari itu, menurut Rizki Putra Dewantoro, dalam diskursus radikalisme mengenai jihad sebagai teror, suaramuhammadiyah.id 
memiliki pandangan yang sama dengan pendapat dan prinsip Muhammadiyah tokoh Pimpinan Pusat Muhammadiyah maupun Majelis Tarjih PP Muhammadiyah. Seperti pandangan Haedar Nashir, Ketua Umum PP. Muhammadiyah, mengenai radikalisme agama yang ditampilkan suaramuhammadiyah.id berikut ini.

\begin{abstract}
"Kenyataan ada radikalisme ekstrem dan mengandung kekerasan pada segelintir kelompok Islam seperti digelorakan Al-Qaida, ISIS, Jamaah Islamiyah, dan gerakan-gerakan serupa terutama yang dilarang di dunia Muslim. Kita semua menentang radikalisme agama seperti itu, termasuk jika dikembangkan di Indonesia. Kita juga secara tegas tidak bersetuju dengan gerakan Islam yang mengusung paham dan aksi menegakkan kekhalifahan atau negara Islam di Indonesia. Sетиа atau mayoritas terbesar umat Islam sudah bersepakat bahwa Indonesia ialah negara hasil konsensus nasional di mana Pancasila sebagai dasar negara sejalan dengan Islam, yang dalam terminologi Muhammadiyah sebagai organisasi Islam modern terbesar di Indonesia dideklarasikan sebagai "Darul Ahdi Wasyahadah", yakni negara Indonesia yang berdasarkan Pancasila merupakan hasil konsensus nasional seluruh golongan termasuk umat Islam yang tidak boleh diingkari oleh siapa pun namun harus diisi atau dibangun sesuai dengan cita-cita kemerdekaan menuju negara yang berkemajuan" (Multiaspek tentang Radikalisme - Suara Muhammadiyah, diakses pada 2 September 2021, 10.00).
\end{abstract}

Menurut Rizki Putra Dewantoro, mengenai kontra-diskursus radikalisme mengenai jihad, sebenarnya suaramuhammadiyah.id tidak secara langsung melawan radikalisme itu, tetapi lebih dengan mengedepankan moderasi. Jalan moderasi sebagai kontra-diskursus radikalisme yang direpresentasikan oleh suaramuhammadiyah.id ini mengikuti sikap organisasi Muhammadiyah dan pandangan-pandangan tokoh Muhammadiyah yang ditampilkan dalam berita-berita dan artikelartikel di suaramuhammadiyah.id. Sebagai contohnya, Rizki menunjukkan isi suaramuhammadiyah.id berikut Wawancara dengan Peneliti melalui WhatsApp (WA), 1 September 2021.

"Di berbagai kesempatan, Ketua Umum PP Muhammadiyah Haedar Nashir selalu menyatakan agar pemerintah tidak terjebak dalam program deradikalisme. Apalagi menjalankan program itu secara nasional. Kalau program deradikalisme diterapkan secara nasional malah akan menciptakan suasana yang menegangkan di seluruh negeri. Daerah yang aman menjadi ikut tidak nyaman. Orang yang tidak tahu malah tertarik untuk ikut menjadi radikal. Selain itu, Muhammadiyah juga selalu mengingatkan pemerintah agar menciptakan kebijakan yang adil yang dapat menyejahterakan rakyat serta menciptakan rasa aman. Muhammadiyah juga mengusung moderasi Islam sebagai ganti dari program deradikalisme yang telah gagal tersebut, Dengan menyebar luaskan pemahaman Islam moderat, paham radikal itu akan tergerus dengan sendirinya" (Suara Muhammadiyah Gelar Seminar Moderasi: Antitesis Radikalisme dan Deradikalisme - Suara Muhammadiyah, diakses pada 2 September 2021, 11.13).

Berkaitan dengan relasi dengan kelompok-kelompok muslim radikal, suaramuhammadiyah.id lebih mementingkan tindakan amar makruf nahi munkar. Menurut Rizki Putra Dewantoro, bahwa prinsip suaramuhammadiyah.id sama seperti Muhammadiyah yaitu beramar makruf nahi munkar (menyeru kepada kebaikan dan menyegah kemungkaran). Beramar makruf dengan cara yang makruf, dan bernahi munkar dengan cara makruf juga. Termasuk mengedepankan moderasi dan memasifkan narasi-narasi alternatif yang mencerahkan. Sebagai contoh, mewartakan berbagai kegiatan positif Muhammadiyah, kegiatan relawan, pembangunan Amal Usaha, prestasi kader Muhammadiyah dan sebagainya, agar masyarakat dan jamaah dapat lebih produktif dalam mengisi kesehariannya (Wawancara dengan Peneliti melalui WhatsApp (WA), 1 September 2021).

Produksi teks NU Online. Sebagai media resmi organisasi NU, perhatian utama NU Online adalah mewartakan pandangan ke-Islaman Nahdliyah atau Aswaja. NU Online adalah sebagai outlet media resminya NU, mempublikasikan pandangan-pandangan resmi Pengurus Besar NU (PBNU), keputusan-keputusan organisasi, dan juga gagasan-gagasan yang berkembang di lingkungan Nahdliyin. Menurut Syafiq Ali, Direktur NU Online, pada dasarnya fungsi NU Online 
adalah untuk membicarakan NU sebagai organisasi masyarakat. Lebih lanjut mengenai NU Online Syafiq mengatakan:

"NU Online sebagai media yang bisa menjadi rujukan warga NU dalam mengambil sikap, atau mencari tahu informasi terkait keputusan-keputusan internal NU. Karena sering kali, bertahuntahun warga NU itu mendapat informasinya sebagian besar dari media luar, bahkan untuk halhal yang sifatnya ke-NU-an. Untuk statement tokoh NU bacanya dari media luar, keputusankeputusan NU bacanya dari media luar yang sering kali ada distorsi karena banyak wartawan umum yang tidak memahami istilah-istilah khusus ke-NU-an, atau konteks yang tidak begitu dipahami. NU online fungsinya ya media resmi NU untuk mewartakan" (Wawancara dengan Peneliti, 29 Januari 2019, di Lippo Kemang Village, Jakarta Selatan).

Di samping itu, bagi NU dan Nahdliyin, NU Online berfungsi sebagai media penyebar visi dan misi NU. Misalnya mengenai penerimaan Pancasila sebagai dasar negara di kalangan Nahdliyin, NU Online berperan dengan membangun narasi yang sesuai dengan khittah NU dengan memperbanyak tulisan-tulisan yang memang berisi ajaran-ajaran keislaman yang moderat. Misalnya peran NU Online dalam memberikan pemahaman kepada warga NU tentang dasar negara adalah dengan memproduksi tulisan-tulisan yang menjelaskan kenapa NU tidak menuntut negara Islam. Menurut Syafiq, ini bukan diskursus yang baru. "Hal-hal itu ditulis ulang untuk menunjukkan bahwa para sesepuh kita sudah pernah mendiskusikan soal ini. Kita bisa merujuk pandangan mereka kenapa mereka menerima Indonesia tidak menuntut negara Islam", jelasnya (Wawancara dengan Peneliti, 29 Januari 2019, di Lippo Kemang Village, Jakarta Selatan).

Dalam menyikapi isu-isu radikalisme, di NU Online relatif tidak ada perbedaan pandangan. Semua hampir sepakat bahwa memang ekremisme keagamaan tidak dibenarkan. Mengenai peran dan fungsi NU Online sebagai kontra-diskursus radikalisme, Syafiq Ali, Redaktur NU Online, menjelaskan bahwa perhatian utama NU online bukan untuk memerangi radikalisme. Peran NU online lebih pada bagaimana membuat ajaran-ajaran NU tetap dipeluk oleh mayoritas Muslim Indonesia. "Kalau ajaran atau tafsir ke-Islaman atau ke-NU-an itu dipeluk oleh mayoritas muslim Indonesia insyaallah muslimnya tidak akan menjadi radikal. Karena NU itu pada dasarnya tawasuth, moderat, toleran, menerima Pancasila, bahkan syariat Islam saja tidak NU tidak mendukung”, jelas Syafiq. Lebih lanjut mengenai hal ini Syafiq Ali mengatakan:

"Perhatian utama NU Online dalam mewartakan pandangan ke-Islaman Nahdliyah atau Aswaja ini tetap dirujuk atau dipeluk oleh mayoritas muslim, maka dengan sendirinya akan bisa menekan radikalisme di Indonesia. Apalagi kemudian, seiring NU online juga banyak dibaca oleh kalangan non-NU, dibaca bukan saja oleh kalangan yang ada di pedesaan tapi juga di urban yang bersentuhan dengan ide-ide transnasional, ide-ide radikal. Bahkan keberadaan NU Online itu bukan untuk mengonter radikalisme. Tetapi untuk mewartakan ideologi keagamaan kita sendiri, pandangan keagamaan kita sendiri, tafsir keagamaan kita sendiri, karena dengan itu kita percaya bisa menekan derajat radikalisme" (Wawancara dengan Peneliti, 29 Januari 2019, di Lippo Kemang Village, Jakarta Selatan).

Dalam upaya kontra-diskursus radikalisme, NU Online merepresentasikannya dengan memperbanyak tulisan-tulisan yang menjelaskan tentang konsep-konsep ke-Islaman yang terkait dengan radikalisme. Misalnya mengenai jihad, khilafah, pemimpin nonmuslim, mayotirani Islam, dan mengenai tidak boleh menyerupai orang nonmuslim dan seterusnya. "NU online masuk ke isuisu yang memang menjadi diskursus banyak orang, terutama diskursusnya orang-orang di luar NU karena pada dasarnya sebagian besar orang NU tidak begitu terpengaruh dengan diskursusdiskursus itu. Kalau kita cari tidak ada kiai NU yang setuju khilafah Islamiyah atau ISIS”, jelas Syafiq.

Konsumsi teks suaramuhammadiyah.id. Jihad dalam pandangan warga dan tokoh-tokoh Muhammadiyah adalah bersungguh-sungguh di jalan Allah Swt. dan menolak jihad dalam pengertian peperangan dan terorisme. Seperti pandangan Husnan Nurjuman, Wakil Sekretaris 
Majelis Pembina Kesehatan Umum (MPKU) PP. Muhammadiyah, bahwa jihad tidak melulu dimaknai sebagai peperangan secara fisik melawan orang kafir (berbeda agama) atau orang-orang yang munafik, jihad harus dipahami sebagai upaya secara sungguh-sungguh. Secara bahasa, jihad adalah sungguh-sungguh dalam hal apapun, terutama adalah upaya yang sungguh-sungguh untuk mengamalkan nilai-nilai ajaran Islam (Wawancara dengan Peneliti, 12 Maret 2020, melalui e-mail). Begitu juga pandangan Pradana Boy, Anggota Majelis Tarjih dan Tajdid PWM Jawa Timur, yang memahami jihad pada dasarnya berarti berusaha keras, tekun bekerja, berjuang dan mempertahankan. Lebih jauh, jihad adalah bersungguh-sungguh dalam menjalankan setiap perbuatan baik. Dalam konteks ini, makna jihad sangat luas (Wawancara dengan Peneliti, 24 Maret 2020, melalui e-mail).

Sebagai usaha sungguh-sungguh di jalan Allah, makna jihad menjadi sangat luas, setiap usaha yang sungguh-sungguh di jalan Allah atau niat semata mencari ridha Allah adalah jihad. Bekerja untuk menafkahi anak, istri, dan orang tua itu jihad fii sabilillah. Jadi makna jihad menjadi sangat luas. Menurut Makmun Murod, Wakil Sekretaris Lembaga Hikmah dan Kebijakan Publik (LKHP) PP. Muhammadiyah, jihad dalam Islam harus dikaitkan dengan fii sabilillah. Sebab kalau tidak ada kata fii sabilillah bisa berubah artinya. Makmun menjelaskan, "jihad kan artinya usaha sungguhsungguh, maka harus dirangkai dengan fii sabilillah, usaha sungguh-sungguh di jalan Allah (Wawancara dengan Peneliti, 25 Maret 2020, melalui e-mail).

Berkaitan dengan jihad lil-muwajahah pada dasarnya, seperti yang disampaikan oleh Pradana Boy, sejalan dengan makna dasar jihad dan sekaligus hakikat Muhammadiyah sebagai gerakan Islam modern. Terlebih belakangan ini, Muhammadiyah selalu mencitrakan diri sebagai Islam Berkemajuan. Salah satu ciri utama kemajuan adalah mengajukan alternatif-alternatif (Wawancara dengan Peneliti, 24 Maret 2020, melalui e-mail). Dari sudut yang lain, Makmun Murod menyatakan sangat bersepakat dengan tafsir Muhammadiyah terkait dengan jihad lil-muwajahah. Penafsiran ini untuk membedakan dengan pengertian jihad yang selama ini dipahami sekadar bil lafdzi (hanya sekadar di mulut), atau sebaliknya di titik ekstrem lainnya, jihad dipahami begitu menakutkan seperti meledakkan bom, dan sebagainya (Wawancara dengan Peneliti, 25 Maret 2020, melalui email). Mengenai jihad sebagai upaya sungguh-sungguh menciptakan suatu alternatif yang unggul, menurut pandangan Husnan Nurjuman:

Perkembangan teknologi dan kehidupan dunia modern, perkembangan peradaban Barat yang di satu sisi juga melahirkan berbagai kegelisahan manusia modern seperti masalah lingkungan, eksploitasi manusia, kesenjangan ekonomi, bias gender dan masalah kemanusiaan lainnya. Lalu munculnya berbagai gerakan Islam dengan ideologi yang kontra-produktif dengan kemajuan umat, maka jihad yang dilakukan Muhammadiyah adalah memunculkan berbagai alternatif dengan keunggulan yang menandingi alternatif lain yang telah ada atau yang baru muncul (Wawancara dengan Peneliti, 12 Maret 2020, melalui e-mail).

Konsumsi teks NU Online. Warga dan tokoh-tokoh NU secara umum menolak pandangan jihad dalam bentuk kekerasan, peperangan, dan terorisme. Seperti pandangan Syafiq Ali, Sekretaris Lembaga Ta'lif wan-Nasyr PBNU, bahwa jihad dapat dimaknai secara luas dan kontekstual. Jihad adalah semangat untuk membela yang memang terancam, dan memperjuangkan apa yang dianggap benar oleh agama. Syafiq mengatakan, "ketika dijajah dan bangkit melawan, itu juga jihad. Selain itu, orang-orang yang sedang memperjuangkan kepentingan mereka yang lemah, menghadapi kekuatan yang hegemonik, yang menindas itu jihad. Memperjuangkan tujuan dasar agama, syiar agama itu juga layak disebut jihad. Selama ini jihad selalu dipahami perang karena konteksnya yang diceritakan sejarah Nabi dan sahabat itu perang, padahal pada masa kehidupan Nabi perang hanya beberapa kali. Jadi, jihad itu banyak konteksnya" (Wawancara dengan Peneliti, 16 April 2020, melalui telepon). 
Maka dari itu, menurut Alissa Qotrunnada Munawaroh Wahid (Alissa Wahid), Sekretaris Lembaga Kemaslahatan Keluarga PBNU, jihad adalah sebagai mabadi' khaira ummah (mengutamakan kemaslahatan umat). Membangun khaira ummah itu salah satu bentuk jihad. Jihadnya orang NU itu wujudnya bukan berperang, tetapi membangun khaira ummah. Mabadi' khaira ummah itu sebagai salah satu bentuk jihad. Tidak sama dengan jihad, tetapi bagian dari jihad (Wawancara dengan Peneliti, 17 Maret 2020, melalui telepon). Sedangkan dalam pandangan Khamami Zada, Wakil Ketua Lakpesdam PBNU, jihad sebagai mabadi' khaira ummah termasuk dalam kategori jihad yang non-fisik, yaitu mengerahkan segenap kemampuan untuk mewujudkan kemaslahatan masyarakat, seperti mengajarkan ilmu, berdakwah, dan berbakti kepada orang tua. Penafsiran NU terhadap jihad seperti di atas adalah penafsiran yang progresif agar umat Islam tidak terjebak dalam pemahaman jihad sebagai perang saja (Wawancara dengan Peneliti, 17 Maret 2020, melalui e-mail). Berkaitan dengan konsep mabadi' khaira ummah, Alissa Wahid menjelaskan sebagai berikut:

"Mabadi' khaira ummah adalah langkah-langkah awal menuju khaira ummah, dalam konsep aslinya begitu. Kiai Mahfudz Shiddiq waktu itu mengatakan bahwa orang-orang NU itu harus memperbaiki dirinya supaya kapasitasnya lebih baik dan memunyai daya saing. Itu konsep aslinya begitu. Supaya bisa menjadi khaira ummah, mabadi'nya bagaimana? Langkah-langkah pertamanya bagaimana? Itulah yang kemudian disebut sebagai gerakan mabadi' khaira ummah, yaitu menumbuhkan tiga karakter yang dianggap karakter yang penting untuk mewujudkan khaira ummah itu. Konsep mabadi' khaira ummah ini kemudian diperkuat menjadi lima poin, dan bukan hanya menjadi watak dan karakter seorang Nahdliyin saja tapi menjadi karakter dan kultur NU sebagai organisasi" (Wawancara dengan Peneliti, 17 Maret 2020, melalui telepon).

Dengan demikian, produksi teks NU Online mengenai makna jihad yang direpresentasikan secara kontekstual dalam berbagai bentuk jihad seperti jihad melawan narkoba, jihad melawan hoaks, jihad melawan korupsi, dan bentuk-bentuk jihad lainnya merupakan aktualisasi dari jihad sebagai mabadi' khaira ummah ini.

\section{c. Analisis Sosio-Kultural: Radikalisme di Ranah Publik Baru}

Dalam perkembangannya, seiring dengan kemajuan teknologi informasi dan komunikasi yang sedemikian pesat saat ini, maka diskursus radikalisme pun bergeser dari ranah publik konvensional, seperti ruang-ruang publik di kelas, seminar, dan media massa konvensional ke ranah publik baru, yang berbasis jaringan internet dalam bentuk media online, media baru, dan media sosial. Konsep ruang publik (public sphere) digagas oleh Jurgen Habermas yang merupakan jaringan untuk mengomunikasikan informasi dan juga pandangan. Ranah publik berkaitan dengan opini publik, istilah yang mengacu fungsi kritik dan kontrol oleh publik. Berkaitan dengan fungsi opini publik, ranah publik sebagai ranah yang menghubungkan antara negara dan masyarakat, ranah di mana publik sebagai sarana opini publik (Habermas, 2009). Ranah publik merupakan bagian mendasar dari organisasi sosial-politik karena ia adalah ranah orang-orang datang bersama sebagai warga negara dan mengartikulasikan pandangan-pandangan bebasnya untuk mempengaruhi institusi politik di masyarakat (Castells, 2010).

Konsep ranah publik kemudian diperluas pemahamannya dengan istilah atau konsep ranah publik baru (the new public sphere). Terdapat dua hal yang membedakan konsep ranah publik dengan ranah publik baru. Pertama, berkaitan dengan sistem komunikasi yang terlibat di dalamnya. Ranah publik baru digerakkan oleh sistem komunikasi multimodal karena internet dan jaringan komunikasi horizontal memainkan peran yang menentukan. Terdapat pergantian dari ranah publik yang berpijak pada lembaga-lembaga nasional dari masyarakat dengan batas-batas teritorial ke arah ranah publik yang berpangkal pada sistem media. Sistem media ini disebut sebagai mass self- 
communication, yakni jaringan komunikasi yang menghubungkan banyak ke banyak (many to many) dalam mengirim dan menerima pesan-pesan (Castells, 2008, 2010).

Kedua, berkaitan dengan partisipan atau aktor yang terlibat dalam pembentukan demokratisasi publik, yaitu negara, lembaga antar-pemerintah, dan masyarakat sipil. Ranah publik global baru dibangun melalui sistem komunikasi dan jaringan internet, seperti YouTube, MySpace, Facebook, Instagram, dan lain-lainnya. Maka dari itu penting bagi para aktor tersebut untuk saling menjalin hubungan dalam semacam debat publik dalam ranah publik global. Dengan demikian, konsolidasi ranah publik berbasis komunikasi menjadi salah satu kunci dengan mana negara dan lembagalembaga internasional dapat terikat dalam sebuah proyek masyarakat sipil global (Castells, 2008, 2010).

Radikalisme sebagai salah satu isu global tentu menjadi perhatian banyak kalangan, baik negara, lembaga antar-pemerintah, dan masyarakat sipil. Berkaitan dengan diskursus radikalisme di ranah publik baru, dapat dilihat bagaimana isu radikalisme ini dibicarakan dan dikonstruksi maknanya oleh berbagai kalangan di ranah publik baru, seperti bentuk-bentuk media baru yang berbasis internet. Salah satu alasan mengapa radikalisme menjadi isu global adalah karena peran media-media baru tersebut. Kelompok-kelompok muslim fundamentalis, misalnya, menggunakan internet untuk mengartikulasikan identitas global dan lokal mereka, yang mencakup politik, komersial, ideologis, bahasa, dan komunikasi atau interaksi menggunakan website. Al-Qaeda, misalnya, jaringan gerakannya dioperasikan melalui worldwide dengan berbagai liputan agenda politik mereka (Khatib, 2019). Al-Qaeda juga sering kali menggunakan al-Jazeera, sebuah jaringan televisi muslim independen, sebagai alternatif CNN (Castells, 2004).

Pada konteks Indonesia, media-media online telah lama dimanfaatkan oleh kelompokkelompok muslim radikal sebagai ladang penyemaian benih-benih pemahaman radikal melalui diskursus yang mereka munculkan. Kelompok-kelompok muslim radikal, seperti Jamaah Anshorut Tauhid (JAT), Majelis Mujahidin Indonesia (MMI), dan Hizbut Tahrir Indonesia (HTI) menggunakan media-media online mereka miliki, yakni situs JAT (ansharuttauhid.com), situs MMI (majelismujahidin.com), dan situs HTI (hizbut-tahrir.or.id) untuk mengonstruksi pandanganpandangan mereka mengenai isu-isu yang berkaitan dengan nilai-nilai demokrasi seperti isu Hak Asasi Manusia (HAM), kebebasan beragama, kelompok minoritas, dan kebebasan berekspresi (Karman, 2015).

Bahkan dalam perkembangan, kelompok-kelompok muslim radikal juga menggunakan mediamedia sosial seperti Youtube, Twitter, Instagram, dan sebagainya sebagai media penyebaran pandangan-pandangan radikal mereka (Muthohirin, 2015). Terdapat peran yang sangat signifikan dari media-media sosial seperti Facebook dan Twitter sebagai arena baru penyemaian dan propaganda kelompok-kelompok muslim radikal seperti HTI, Harakah Tarbiyah dan Jamaah Salafi. Sasarannya adalah kaum muda yang memang dekat dengan media-media sosial sehingga pesanpesan radikalisme lebih mudah diterima (Muthohirin, 2015). Termasuk menyasar kalangan mahasiswa melalui organisasi-organisasi mahasiswa di kampus-kampus Islam, seperti Lembaga Dakwah Kampus (Afrianty, 2012).

Adanya konteks sosio-kultural politik, yakni bahaya laten paham radikalisme agama dan meningkatnya peran media online dan media sosial, serta media-media berbasis jaringan internet lainnya sebagai media baru dalam penyebarluasan paham radikalisme, perlu diantisipasi dan ditandingi dengan peningkatan peran media-media serupa dari pemerintah dan organisasiorganisasi Islam moderat seperti Muhammadiyah dan NU. Melalui suaramuhammadiyah.id dan NU Online, kontra-diskursus radikalisme mengenai jihad dapat dilakukan dengan menampilkan penafsiran-penafsiran dan pemahaman-pemahaman yang lebih kontekstual mengenai isu-isu radikalisme, seperti dasar negara, jihad, dan toleransi terhadap nonmuslim di ranah publik baru. 


\subsection{Pembahasan: Diskursus dan Kontra-Diskursus Radikalisme di Media Online}

Istilah diskursus dipopulerkan oleh Michel Foucault. Diskursus merupakan keseluruhan domain (bidang) yang mana bahasa digunakan dengan pola-pola tertentu. Diskursus dapat diartikan sebagai keseluruhan wilayah konseptual karena pengetahuan diciptakan atau dibentuk, dan diproduksi (Lubis, 2014). Diskursus dalam kaitannya dengan pemahaman terhadap teks, adalah setiap bahasa yang dibakukan lewat tulisan. Maka, diskursus selalu berkaitan dengan bahasa yang digunakan. Bahasa dalam diskursus dianggap sebagai peristiwa (event), yakni bahasa yang membincangkan sesuatu (Ricoeur, 2006). Jadi, diskursus adalah bahasa ketika ia digunakan untuk berkomunikasi (Permata, 2013).

Sedangkan kontra-diskursus, dalam pandangan Foucault berkaitan dengan kelompok yang sebelumnya tidak bersuara kemudian mulai mengartikulasikan keinginan mereka untuk melawan dominasi wacana otoritatif yang berlaku (Moussa \& Scapp, 1996). Kontra-diskursus adalah semacam perlawanan dengan memproduksi diskursus tandingan. Akan tetapi, dalam kontradiskursus apa yang digambarkan dan diinterpretasikan berbeda dengan apa yang digambarkan dan ditafsirkan dalam diskursus. Sebagai contoh, istilah Occidentalism sebagai kontra-diskursus istilah orientalism, atau dalam posisi biner seperti West-East, Self-Other, Oppressed-Oppressor (Sorensen \& Chen, 1996). Kontra-diskursus juga dapat berbentuk, misalnya, istilah post-colonial sebagai kontra-diskursus kolonialisme dan imperialisme (Tiffin, 1987).

Dalam konteks penelitian ini, diskursus radikalisme ditampilkan oleh media-media online yang berafiliasi kepada kelompok-kelompok muslim radikal, seperti Jamaah Anshorut Tauhid (JAT), Majelis Mujahidin Indonesia (MMI), dan Hizbut Tahrir Indonesia (HTI). Melalui mediamedia online yang dimiliki, mereka mengonstruksi diskursus mengenai isu-isu seperti sistem pemerintahan, jihad, dan toleransi sesuai dengan pandangan dan kepentingan mereka. Pada isu sistem pemerintahan, misalnya, mereka menolak sistem demokrasi, termasuk demokrasi Pancasila dan menggagas sistem pemerintahan khilafah yang berasaskan syariat Islam. Begitu pula pada isu jihad, dalam pandangan mereka jihad adalah memerangi orang-orang kafir sebagai musuh Islam dengan kekerasan dan terorisme. Termasuk mengenai toleransi yang dipandang sebagai akal-akalan kelompok-kelompok nonmuslim agar dapat menyingkirkan umat Islam (Afrianty, 2012; Karman, 2015; Muthohirin, 2015).

Diskursus radikalisme yang ditampilkan media-media online kelompok-kelompok muslim radikal mengenai berbagai isu tersebut itulah yang kemudian ditandingi dan dilawan melalui kontra-diskursus radikalisme oleh media-media online yang dimiliki oleh organisasi-organisasi Islam moderat Muhammadiyah dan NU, yakni suaramuhammadiyah.id dan NU Online. Kontradiskursus, sebagaimana dijelaskan, adalah semacam perlawanan dengan memproduksi diskursus tandingan untuk melawan dominasi wacana otoritatif yang berlaku (Moussa \& Scapp, 1996). Sebagai kontra-diskursus radikalisme, suaramuhammadiyah.id dan NU Online menampilkan diskursus tandingan dalam bentuk atau makna yang berbeda mengenai jihad.

Mengenai jihad, suaramuhammadiyah.id menampilkan diskursus jihad sebagai jihad lilmuwajahah (berjuang sungguh-sungguh menciptakan suatu alternatif yang unggul) sebagai kontradiskursus jihad kekerasan, peperangan, dan terorisme. Diskursus jihad sebagai jihad lil-muwajahah oleh suaramuhammadiyah.id diaktualisasikan dalam berbagai bentuk dan makna jihad, seperti jihad konstitusi, jihad politik, jihad sosial, jihad melawan korupsi dan melawan covid-19, serta maknamakna jihad kontekstual lainnya. Sedangkan NU Online merepresentasikan makna jihad dalam diskursus penolakan jihad sebagai kekerasan, peperangan, dan terorisme. Diskursus jihad oleh NU Online direpresentasikan secara lebih kontekstual, seperti jihad melawan korupsi, antinarkoba, 
jihad melawan hoaks, dan sejenisnya sebagai kontra-diskursus makna jihad kekerasan, peperangan, dan terorisme yang ditampilkan oleh media-media online kelompok-kelompok muslim radikal.

Pada sisi yang lain, kontra-diskursus radikalisme mengenai jihad yang ditampilkan oleh suaramuhammadiyah.id dan NU Online dapat dipandang juga sebagai bentuk kontra-hegemoni atas pemahaman jihad sebagai kekerasan, peperangan, dan terorisme yang selama ini dianggap dominan. Selama ini pemahaman mengenai jihad dari kelompok-kelompok muslim radikal terlihat dominan dan menguasai ranah publik baru. Mereka menjadi kelompok dominan meski tidak pada wujud kontrol politik dan ekonomi, tetapi lebih pada kemampuan mereka mengatur cara-cara yang mereka miliki dalam memandang dunia untuk diikuti dan ditanamkan kepada kelompok-kelompok lain sehingga pandangan mereka mengenai jihad sebagai kekerasan, peperangan, dan terorisme dianggap sebagai hal yang "lumrah" dan "alamiah".

Istilah kontra-hegemoni lahir dari pemikiran Gramsci, yakni semacam perang posisi atau kultural dalam jangka panjang. Dalam proses perang posisi ini peran intelektual organik sangat menentukan, karena hegemoni sebagian besar diperoleh dan dimantapkan melalui pendidikan (Magnis-Suseno, 2003). Pada tataran diskursus, apa yang ditampilkan oleh suaramuhammadiyah.id dan NU Online merupakan upaya atau tindakan penyadaran atau pembebasan dari pemahaman radikalisme mengenai jihad yang dianggap tidak sesuai di Indonesia. Dengan merepresentasikan diskursus jihad sebagai jihad lil-muwajahah dan jihad yang kontekstual, suaramuhammadiyah.id dan NU Online berupaya melakukan kontra-hegemoni terhadap diskursus radikalisme mengenai jihad yang selama ini dianggap dominan dan hegemonik, bahwa jihad adalah melakukan tindakan kekerasan, peperangan, dan terorisme melawan orang-orang kafir musuh-musuh Islam.

Kontra-hegemoni oleh suaramuhammadiyah.id dan NU Online terhadap hegemoni pemahaman radikalisme dapat dilakukan dengan terus menerus memproduksi pemahaman atau penafsiran baru secara lebih kontekstual mengenai isu-isu utama radikalisme, bukan hanya mengenai jihad, melainkan juga mengenai bentuk negara Pancasila dan toleransi terhadap nonmuslim. Pemahaman yang kontekstual mengenai isu-isu radikalisme tersebut harus terus ditanamkan ke dalam benak masyarakat, khususnya warga Muhammadiyah dan NU sebagai kontra-diskursus radikalisme melalui diskursus yang dimunculkan di media massa online suaramuhammadiyah.id dan NU Online.

\section{PENUTUP}

Kontra-diskursus radikalisme mengenai jihad di suaramuhammadiyah.id adalah dengan merepresentasikan jihad sebagai jihad lil-muwajahah (berjuang menciptakan sesuatu yang unggul). Adapun NU Online merepresentasikan jihad secara lebih kontekstual, seperti jihad melawan korupsi, melawan narkoba, melawan hoaks, dan lain sebagainya. Representasi suaramuhammadiyah.id dan NU Online ini merupakan kontra-diskursus radikalisme mengenai jihad sebagai kekerasan, perang, dan terorisme dari kelompok-kelompok muslim radikal. Kontradiskursus radikalisme mengenai jihad oleh suaramuhammadiyah.id dan NU Online tidak lepas dari identitas kedua media online resmi organisasi Islam yakni Muhammadiyah dan NU yang moderat. Sebagai media yang menyuarakan kepentingan dan paham moderat, suaramuhammadiyah.id dan NU Online memiliki relasi yang bertolak belakang dengan kelompok-kelompok muslim radikal dalam memaknai jihad.

Kontra-diskursus radikalisme mengenai jihad yang direpresentasikan oleh suaramuhammadiyah.id dan NU Online dilingkupi situasi karena muncul fenomena kebangkitan kembali gerakan radikalisme di Indonesia pasca-runtuhnya Orde Baru. Kelompok-kelompok muslim radikal ini menggunakan media-media massa online dan media-media sosial sebagai media 
penyebaran gagasan radikalisme. Mereka menggunakan media-media baru (new media) untuk mengonstruksi pandangan-pandangan mereka mengenai isu-isu demokrasi seperti HAM, kebebasan beragama, kelompok minoritas, dan kebebasan berekspresi. Maka dari itu, Media online suaramuhammadiyah.id dan NU Online sangat berperan penting dalam upaya melakukan kontradiskursus radikalisme dengan merepresentasikan diskursus mengenai jihad secara lebih kontekstual, sekaligus sebagai kontra-hegemoni atas diskursus yang dimunculkan oleh mediamedia online kelompok-kelompok muslim radikal mengenai jihad sebagai kekerasan, peperangan, dan terorisme.

Sebagai rekomendasi, suaramuhammadiyah.id dan NU Online sebenarnya sudah banyak menampilkan kontra-diskursus radikalisme mengenai jihad dalam berita-berita dan artikelartikelnya. Upaya ini tetap harus dipertahankan, bila perlu ditingkatkan frekuensinya agar kesadaran anti-radikalisme di kalangan Muhammadiyah dan NU tetap terjaga, terutama para generasi mudanya yang kemungkinan lebih rentan terpapar radikalisme. Selain itu, seiring dengan pesatnya perkembangan teknologi informasi dan komunikasi, terutama media-media sosial baru, suaramuhammadiyah.id dan NU Online perlu mengadopsi dan mengembangkan bentuk-bentuk teknologi baru tersebut sebagai media diskursus baru, sekaligus sebagai media baru kontradiskursus radikalisme.

\section{Ucapan Terima Kasih}

Penulis mengucapkan terima kasih kepada semua pihak yang membantu dalam studi dan penulisan artikel ini.

\section{DAFTAR PUSTAKA}

Afrianty, D. (2012). Islamic education and youth extremism in Indonesia. Journal of Policing, Intelligence and Counter Terrorism, 7(2), 134-146. https://doi.org/10.1080/18335330.2012.719095

Azman. (2015). Jihad Perspektif Hizbut Tahrir Indonesia. Al Daulah : Jurnal Hukum Pidana Dan Ketatanegaraan. https://doi.org/10.24252/AD.V4I1.1498

Azra, A. (2016). Transformasi Politik Islam Radikalisme, Khilafatisme, dan Demokrasi. Jakarta: Prenada Media.

Binfas, Maman A. Majid, Fitriani, S., \& Wahjusaputri, S. (2018). Muhammadiyah-Nahdlatul Ulama (NU): Monumental Cultural Creativity Heritage of The World Religion. Epistemé: Jurnal Pengembangan Ilmu Keislaman, 13(1), 173-193. https://doi.org/10.21274/epis.2018.13.1.173-193

Binfas, Maman Abdul Majid, Abdullah, M. S. Y., \& Ismail, A. M. (2014). Tapak perbezaan asal usul gerakan Muhammadiyah dan Nahdlatul Ulama (NU) di Indonesia. Jurnal Melayu, 12(1), 14-31. https://ejournal.ukm.my/jmelayu/article/view/6615/0

Burhani, A. N. (2012). Al-Tawassut wa-l I'tidāl: The NU and moderatism in Indonesian Islam. Asian Journal of Social Science, 40(5-6), 564-581. https://doi.org/10.1163/15685314-12341262

Burhani, A. N. (2013). Liberal and Conservative Discourses in the Muhammadiyah: The Struggle for the Face of Reformist Islam in Indonesia. In M. Van Bruinessen (Ed.), Contemporary Developments in Indonesian Islam (pp. 105-144). ISEAS-Yusof Ishak Institute Singapore. https://doi.org/10.1355/9789814414579-008

Castells, M. (2004). The Power of Identity. Victoria: Blackwell Publishing.

Castells, M. (2008). The new public sphere: Global civil Society, communication networks, and global governance. Annals of the American Academy of Political and Social Science, 616(1), 78-93. https://doi.org/10.1177/0002716207311877

Castells, M. (2010). The New Public Sphere: Global Civil Society, Communication Network, and Global Governance. In D. K. Thussu (Ed.), International Commnucation A Reader (pp. 36-47). New York: Routledge.

Fadli, R. (2019). Kontra Radikalisme Agama di Dunia Maya (Studi Analisis Portal Online Organisasi Islam dan Pemerintah) [Universitas Islam Negeri Walisongo Semarang]. http://eprints.walisongo.ac.id/9940/

Fairclough, N. (1995). Media Discourse. New York: St. Martin's Press Inc.

Fairclough, N. (2010). Critical Discourse Analysis the Critical Study of Language. Edinburgh: Logman 
Applied Linguistics.

Fairclough, N. (2013). Critical discourse analysis and critical policy studies. Critical Policy Studies, 7(2), 177-197. https://doi.org/10.1080/19460171.2013.798239

Flew, T. (2005). New Media an Introduction. Victoria: Oxford University Press.

Fuad, A. F. (2015). Islamisme dan Dakwah di Indonesia: Perspektif dan Pengalaman Dakwah Gerakan Tarbiyah. Jurnal Ilmu Komunikasi Komunika, 10(1), 82-92.

Habermas, J. (2009). The Public Sphere. In S. Thornham, C. Basset, \& P. Marris (Eds.), Media Studies A Reader (3rd ed., pp. 45-51). Edinburgh: Edinburgh University Press.

Hasan, N. (2005). September 11 and Islamic Militancy in Post-New Order Indonesia. In K. S. Nathan \& M. H. Kamali (Eds.), Islam in Southeast Asia: Political, Social and Strategic Challenges for the 21st Century (1st ed., pp. 301-324). Singapore: Institute of Southeast Asian Studies.

Hasan, N. (2008). Laskar Jihad Islam, Militansi, dan Pencarian Identitas di Indonesia Pasca-Orde Baru (Hairus Salim) (1st ed.). Jakarta: LP3ES-KITLV.

Hilmy, M. (2013). Whiter Indonesia's Islamic Moderatism? A Reexamination on the Moderate Vision of Muhammadiyah and NU. JOURNAL OF INDONESIAN ISLAM, 7(1), 24. https://doi.org/10.15642/JIIS.2013.7.1.24-48

Ichwan, M. N. (2013). Towards a Puritanical Moderate Islam: The Majelis Ulama Indonesia and the Politics of Religious Orthodoxy. In M. Van Bruinessen (Ed.), Contemporary Developments in Indonesian Islam (pp. 60-104). ISEAS-Yusof Ishak Institute Singapore. https://doi.org/10.1355/9789814414579-007

Karman. (2015). Construction Of Democratic Values By Islam-Based Fundamentalist-Groups In Online Media. Jurnal Pekommas, 18(3), 181-190. https://doi.org/https://dx.doi.org/10.30818/jpkm.2015.1180304

Khatib, L. (2019). Communicating Islamic Fundamentalism as Global Citizenship. In D. K. Thussu (Ed.), International Communication A Reader (pp. 279-294). New York: Routledge.

Lister, M., Dovey, J., Giddings, S., Grant, I., \& Kelly, K. (2009). New Media a Critical Introduction. London and New York: Routledge.

Lubis, A. A. (2014). Filsafat Ilmu Klasik hingga Kontemporer. Jakarta: Rajawali Press.

Magnis-Suseno, F. (2003). Dalam Bayang-bayang Lenin: Enam Pemikir Marxisme dari Lenin sampai Tan Malaka. Jakarta: Gramedia Pustaka Utama.

McQuail, D. (2010). Mass Communication Theory (6th ed.). London, Sage Publication.

Moussa, M., \& Scapp, R. (1996). The Practical Theorizing of Michel Foucault: Politics and CounterDiscourse. Cultural Critique, 33, 87-112. https://doi.org/10.2307/1354388

Mubarak, M. Z. (2007). Genealogi Islam Radikal di Indonesia: Gerakan, Pemikiran dan Prospek Demokrasi. Jakarta: LP3ES.

Muthohirin, N. (2015). Radikalisme Islam dan Pergerakannya di Media Sosial (Islamic Radicalism and its Movement on Social Media). Jurnal Afkaruna. https://doi.org/10.18196/AIIJIS.2015.

Nashir, H., Qodir, Z., Nurmandi, A., Jubba, H., \& Hidayati, M. (2019). Muhammadiyah's Moderation Stance in the 2019 General Election: Critical Views from Within. Al-Jami'ah: Journal of Islamic Studies. https://doi.org/10.14421/ajis.2019.571.1-24

Nurrohman, M. (2019). Analisis Isi Media NU Online tentang Radikalisme [UIN Walisongo Semarang]. http://eprints.walisongo.ac.id/10833/

Permata, A. N. (2013). Hermeneutika Fenomenologis Paul Rioeur. In E. Mulyono, N. Atho', \& A. Fakhrudin (Eds.), Belajar Hermeneutika Dari Konfigurasi Filosofis menuju Praksis Islamic Studies (2nd ed., pp. 242-270). Yogyakarta: IRCsoD.

Rahman, T. (2017). Contextualizing jihad and mainstream Muslim identity in Indonesia: the case of Republika Online . Asian Journal of Communication, 27(4), 378-395. https://doi.org/10.1080/01292986.2016.1278251

Ricoeur, P. (2006). Hermeneutika Ilmu Sosial (Muhammad Syukri). Yogyakarta: Kreasi Wacana.

Saputra, R., \& Nazim, A. M. (2017). Strategi Dakwah Islam melalui Media Online Nahdlatul Ulama. MALAYSIAN JOURNAL FOR ISLAMIC STUDIES, $2, \quad$ 9-18. https://journal.unisza.edu.my/mjis/index.php/mjis/article/view/22

Sefriyono, S. (2020). Jihad Digital: Pembingkaian Narasi Kontra Radikalisasi NU Online di Dunia Maya. FIKRAH, 8(1), 19. https://doi.org/10.21043/fikrah.v8i1.7214

Sorensen, S., \& Chen, X. (1996). Occidentalism: A Theory of Counter-Discourse in Post-Mao China. World Literature Today. https://doi.org/10.2307/40152267

Sukmono, F. G., \& Junaedi, F. (2020). Manajemen Konten dan Adaptasi Suara Muhammadiyah di Era Digital. Jurnal Komunikasi Global, 9(2), 248-265. https://doi.org/10.24815/jkg.v9i2.17845

Tiffin, H. (1987). Post-Colonial Literatures and Counter-Discourse. Kunapipi, 9(3), 17-34. https://ro.uow.edu.au/kunapipi/vol9/iss3/4/ 
Van Bruinessen, M. (2013). Introduction: Contemporary Developments in Indonesian Islam and the "Conservative Turn" of the Early Twenty-First Century. In M. Van Bruinessen (Ed.), Contemporary Developments in Indonesian Islam: Explaining the "Conservative Turn" (pp. 1-20). ISEAS-Yusof Ishak Institute Singapore. https://www.degruyter.com/document/doi/10.1355/9789814414579-005/html

Wijayanti, Y. T. (2020). Radicalism Prevention through Propaganda Awareness on Social Media. Jurnal ASPIKOM, 5(1), 142. https://doi.org/10.24329/aspikom.v5i1.501 
JURNAL STUDI KOMUNIKASI DAN MEDIA

Vol. 25 No. 2 Desember 2021 Hal : 151 - 172 